\title{
The Instructional Leadership Practices of School Heads
}

\author{
Joseph Jay U. Aureada
}

\begin{abstract}
This qualitative research study investigated the instructional leadership practices of the school heads in the City Schools Division of Tayabas City and related them to the students' achievement. Using purposive sampling, a triangulation approach as used to interview a total of 55 teachers and 25 school heads who were responsible for grade 6 students. The 60 -minute interviews were held at the school premises during the visitation and monitoring period. It also evaluated several documents and the National Achievement Test. The results showed school heads mostly carried out functions related to mission, management of curriculum and instruction, supervision and support teaching, monitoring of student progress and promoting an effective instructional climate. However, there was no proper monitoring and evaluation. The teachers' competencies, or the lack of it, have not been closely monitored and evaluated. It was concluded that school heads had more difficulties fulfilling duties related to teaching and learning than managerial functions. The results are beneficial to the school superintendent as baseline for the continuous improvement of the instructional leadership. It is highly beneficial for the conduct of further research correlating the instructional leadership with the students' academic achievement.
\end{abstract}

Keywords:

instructional leadership, managing the school, instructional program, student achievement

Suggested Citation: Aureada, J. U. (2021). The Instructional Leadership Practices of School Heads. International Journal of Educational Management and Development Studies, Volume 2, Issue 2, pp. 75 - 89.

About the author:

PhD. Department of Education - City Schools Division, Tayabas City, Philippines 


\section{Introduction}

The role of the school heads is vital to the management of the curriculum as well as the delivery of the instruction. This constitutes instructional leadership which Glanz (2006) refers to as a leadership style that encourages best practices in teaching and Jenkins (2009) as the role of th school principal to promote growth in student learning. Aside from the prime duty of teaching and learning, school heads are responsible for management functions such as scheduling, reporting, handling relations with parents and the community, and dealing with the multiple crisis and special situations that are inevitable in schools (Fink \& Resnick, 2013). Hallinger (2012) concurs that effectiveness is achieved when a correct balance among these roles is attained. For this, Leithwood, Jantzi, and Steinbach (2014) argue that the critical focus for attention by leaders is the behaviors of teachers as they engage in activities directly affecting the growth of students. Thus, school leaders must initiate changes so that teamwork with proper accountability is achived (Ruebling, 2004).

School heads must be true instructional leaders who keep their focus on teaching and learning. School improvements cannot be achieved without the support and participation of school heads (Zheng, 2010). Lip service is a no-no to being an instructional leader but rather school heads must adopt and follow a model that will allow them to accurately and effectively monitor accountability (Leithwood, 2014). The challenge of implementing change in the school community lies on the hands of the school heads. These changes are necessary for the development of the school and instructional development of the teachers so that the students' learning progress continuous. In this cycle, the primary role of the school heads is the initiation of best practices that ultimately lead to improved school performance.

Numerous studies affirm to the positive effect of instructional leadership to students'

academic performance (Ismail et al., 2018; Leithwood, 2014; Johnson, 2006; Khan, et al., 2020). According to Dufour (2011), where school heads are effective instructional leaders, student achievement escalates. In a study conducted by McEwan (2013), it was confirmed that significance between instructional leadership and student achievement exists. It was described that effective or excellent schools has the leadership abilities of the building school heads, particularly in the instructional arena. Moreover, Hou, Cui and Zhang (2019) found that instructional leadership showed a significantly moderating influence on the relationship 
between high school entrance scores and college entrance scores for Chinese students. This relationship was confirmed by Ross and Gray (2006) that principals contribute to student achievement indirectly through teacher commitment and beliefs about their collective capacity which was also explained in the study of Liu, et al. (2020) that instructional leadership is positively and directly associated with teacher self-efficacy. However, Heaven and Bourne (2016) found a positively weak statistical correlation between the performance of students and instructional leadership. Similarly, Dutta and Sahney (2016) found that principal leadership behaviors were not associated directly with either teacher job satisfaction or school-aggregated student achievement.

Eventhough various researches suggest the positive effect of instructional leadership on academic performance, many school leaders failed to manifest instructional leadership practices. There are numerous factors cited on these. Carraway and Young (2014) identify that school heads are uncomfortable visiting teachers' classrooms and have little time focusing on instructional tasks. By redefining the roles of school heads, they become more dynamic and flexible in terms of functions and scope of responsibility.

In this context, school heads are responsible for ensuring improvement process that would impact positive student achievement. In a public school setting, school superintendents need to ensure that school heads are effective instructional leaders. For this, the role of the superintendent encompasses the need to identify school heads' behaviors which exhibit instructional leadership, assess how the school heads are managing the dimensions of instructional leadership, and whether leadership is impacting student achievement positively. They are held accountable for high levels of student achievement. To achieve this, they need to ensure that the entire range of incentives and conditions in schools fully support teaching and learning.

This study was initiated in the City Schools Division of Tayabas City in the Philippines where a one-year professional development plan around instructional leadership for all administrators was developed to assist the school heads in mastering this dimension of leadership. Teaching staff were brought up to date on this program by explaining to them the concept of instructional leadership and identifying what leadership behaviors they could expect their school heads to demonstrate that would affect the quality of teaching positively. 
Specifically, this study examined the behaviors of school heads, determined if school heads' behaviors reflected instructional leadership, and described how teachers perceived the behaviors that school heads. Three sub-questions guided the inquiry.

1. To what extent the school heads demonstrate instructional leadership?

2. How the teachers perceive their school heads' leadership?

3. What is the relationship between the school heads' behaviors and levels of student achievement in grade 6 ?

\section{Literature review}

This study is informed by two areas of literature: accountability in education and leadership. The narrow sense of accountability in education focuses only on student achievement. It is important then to broaden the scope of accountability to include all the various factors the principal is held accountable that affect student achievement.

\subsection{Accountability in education}

Accountability for educators measures more than the test scores which was agreed by the leading advocate on results Schmoker (1999). It includes all the things teachers do to help students learn. It includes both measurable elements of instruction (pedagogy, assessment and teaching strategies) and results (student achievement). Zheng (2010) adds that accountability must include both quantitative and qualitative indicators which should give the complete story behind the results achieved on tests. Teachers feel more comfortable with accountability when it includes more than academic achievement.

Accountability needs to be student-centered or holistic. It needs to refer to a system that includes specific information on curriculum, teaching practices and leadership practices. A student-centered accountability is more constructive than the traditional accountability because it focuses on the improvement of teaching and learning rather than merely rendering an evaluation and the publication of a report (Zheng (2010). It must go beyond the simplistic concept that knowledge is just information and skills that can be codified, simplified, and unchanged (Null, 2011). The heavy emphasis on standardized testing is not always necessary to improve education (Sahlberg, 2015). A new system of accountability must balance qualitative and quantitative measures built on professional responsibility and trust. Under this 
model, the schools work effectively and efficiently toward both the public good and the development of students.

\subsection{Educational leadership}

Leadership has many definitions and styles from getting things done to influencing people. Educational leadership has no exception. For Leithwood, Jantzi, and Steinbach (2014), leadership is usually described using adjectives such as good, effective, exemplary, and poor. It seems easy to measure and equate leadership with different subjective parameters. However, Leithwood (2007) believes that leadership is about the internal state and the overt behavior of leaders. The internal states refer to the values, beliefs, skills or knowledge while overt behavior is the leadership practices. Leaders should put to practice whatever values and skills to be effective. For this, school heads need to create a team spirit so that the academic community functions toward one specific goal (Neuman \& Simmons, 2014).

Leadership can take many forms. There has been new conceptual models of educational leadership (Hallinger, 2012). The most commonly researched styles are situational leadership, servant leadership, constructivist leadership, cultural leadership, instructional leadership, transformational leadership, and moral leadership. Although all of them applies to all types of organizations, instructional leadership specifically address the needs of an academic community which encompasses both the nature of leader and application of leadership in the academic setting. For Leithwood (2014), school leaders must not pay lip service to being an instructional leader.

\section{Methodology}

This study used qualitative research design. The research questions that guided this study call for a qualitative approach since the study is seeking to understand the live experiences of the informants in order to evaluate the link between leadership and student achievement. According to Patton (2012), the qualitative data gathering can take the form of interview, observation, and document analysis. This study used the interview and document analysis strategies. 


\subsection{Interview}

This study interviewed a total of 55 teachers and 25 school heads who were responsible for grade 6 students. The focus of the individual interviews differed. The teachers were asked on their perception on the day-to-day leadership behavior of the school head. On the other hand, school heads shared instructional leadership practices and the day-to-day duties and functions.

The purposive sampling technique was criterion-based wherein all informants must met the entire set of criterion (Patton, 2012). The minimum qualification for the school heads and teachers was at least two years of experience in a school with at least offerings of kindergarten to grade nine.

The interviews were held at the school premises during the visitation and monitoring period. The entire data collection was completed over a three-month period. The participants were interviewed face-to-face for approximately 60 minutes. These were conducted with the use of an interview guide that allowed interviewer the freedom to explore, probe, and ask questions within a topic or subject area. According to Patton (2012), this approach helps interviewer to ask spontaneous questions and establish a conversational style approach to the interview.

Limitation. According to Patton (2012), interview could include distorted responses due to "personal bias, anger, anxiety, politics, and simple lack of awareness since interviews can be greatly affected by the emotional state of the interviewee at the time of the interview." This study notes that data collected through the interview were based on the interpretation of the teachers' experiences while interacting with their school heads. In addition, the school heads' personal assessment of the instructional leadership behaviors is subjective in nature. However, the confidentially of the interviews should have alleviated any need for the school heads and teachers to give a socially desirable response.

\subsection{Document Analysis}

The collected documents consisted of the records maintained by the school heads as part of monitoring activities such as classroom walkthroughs and observations, grade level meetings, discussions with teachers about professional growth plans, school improvement 
plans, staff meeting minutes, quarterly accomplishment report, and achievement results analyses. These documents provided evidence on the presence of instructional practices that contributed to the improvement of teaching and learning process.

For the measurement of the student achievement, data were obtained from the National Achievement Test Results of Grade 6 for the school year 2014-2015.

The qualitative data were analyzed using thematic analysis. These were organized according to themes and categories.

\section{Findings and Discussion}

The data gathered were organized into five broad categories that emerged from the school headsa: vision/goals, learning environment, leadership, accountability, and communication. Each of the broad themes was subdivided into sub-themes.

\section{Table 1}

\section{Emerging Themes and Categories}

\begin{tabular}{cc}
\hline Themes & Categories \\
\hline Vision/goals & Opportunities \\
Learning/achievement & Daily Operations \\
& Student Assessment \\
Community of Learners \\
Leadership & Best Practices \\
& Shared Leadership \\
Accountability & Decision Making \\
& Monitor curriculum alignment \\
& Analyze student work \\
Communication & Student reach learning potential \\
& Visibility \\
& Communication with staff \\
& Meaningful involvement from parents \\
\hline
\end{tabular}

Table 1 shows the emerging five themes which were divided into different categories. Emerging from the data were findings that were organized into five broad themes, which include vision/goals, learning/achievement, leadership, accountability, and communication. 
Each broad theme was further divided into categories. The interview responses were sorted and grouped together. In addition, the documents were analyzed to corroborate with the interview results. The document analysis formed part of the instructional leadership framework.

Table 2

Identified Practices Shared by the School Heads

\begin{tabular}{|c|c|}
\hline Categories & Identified Practices by the School Heads \\
\hline \multirow{4}{*}{ Vision/goals } & Believed that clear vision is essential, \\
\hline & Reviewed and reflected at the start of school plan, \\
\hline & Revisited with parent group and staff, \\
\hline & Modelling of the vision \\
\hline \multirow{3}{*}{ Opportunities } & Various programs were established to support learning needs, \\
\hline & School heads believed the importance of having the best teacher, \\
\hline & $\begin{array}{l}\text { Teachers teach only his/her specialization as opposed to mismatch (major-teaching } \\
\text { load) }\end{array}$ \\
\hline Daily Operations & $\begin{array}{l}\text { presence of timetable, } \\
\text { class program/teacher program was maximized to fit in time for collaboration. }\end{array}$ \\
\hline Student Assessment & $\begin{array}{l}\text { establishment of school wide approach to assessment } \\
\text { provided opportunities for learning }\end{array}$ \\
\hline \multirow{5}{*}{ Community of Learners } & conducted professional development \\
\hline & modelling of 'life-long learning' \\
\hline & engaging in professional reading \\
\hline & attending professional conference \\
\hline & taking graduate course \\
\hline \multirow{3}{*}{ Best Practices } & School to school partnership \\
\hline & Creating networks \\
\hline & Sharing best practices \\
\hline \multirow{5}{*}{ Shared Leadership } & Fostering leadership in others \\
\hline & Supporting leaders \\
\hline & Recognizing teacher's strength \\
\hline & Providing opportunities for leadership roles \\
\hline & Developing leadership abilities \\
\hline \multirow{3}{*}{ Decision Making } & Consultation \\
\hline & Sharing information \\
\hline & Involvement of staff \\
\hline \multirow{3}{*}{$\begin{array}{l}\text { Monitor curriculum } \\
\text { alignment }\end{array}$} & Felt that school head are too busy of operational task \\
\hline & Walk-through is bringing message to them \\
\hline & Felt the school head trusted them to do their job properly \\
\hline \multirow{4}{*}{ Analyze student work } & Believed that professional growth is up to them \\
\hline & School head insisted that they analyze periodical test \\
\hline & Required to inform parents \\
\hline & Expected them to ensure that student reach their learning potential \\
\hline \multirow{3}{*}{$\begin{array}{l}\text { Student reach learning } \\
\text { potential }\end{array}$} & Dialogue was sometimes conducted when there is a problem with students \\
\hline & They are required to conduct interventions \\
\hline & Encouraged to engage in professional development \\
\hline \multirow{2}{*}{$\begin{array}{l}\text { Communication with } \\
\text { staff }\end{array}$} & Expect them to create welcoming environment \\
\hline & PTA volunteerism is encouraged \\
\hline \multirow{4}{*}{$\begin{array}{l}\text { Recognizing } \\
\text { achievement and } \\
\text { improvement }\end{array}$} & Believed that student improvement is ongoing basis \\
\hline & They have choices as to positive reinforcement \\
\hline & Observe sit \\
\hline & Giving positive reinforcement \\
\hline
\end{tabular}


The table 2 shows the data gathered from the interview of the school heads. The 25 school heads answered positively when asked about the manifestation of instructional leadership in daily activities.

Table 3

Identified Practices of School Heads as Perceived by the Teachers

\begin{tabular}{|c|c|}
\hline Categories & Identified Practices by the Teachers \\
\hline Vision/goals & $\begin{array}{l}\text { believed vision is articulated in the school } \\
\text { modelling by staff and administrator, } \\
\text { felt that goals must be learning goals }\end{array}$ \\
\hline \multirow{4}{*}{ Opportunities } & Agreed in the presence of programs \\
\hline & Believed that there are supports available \\
\hline & Felt they were accountable to the students \\
\hline & Believed they must reach out to parents \\
\hline \multirow{3}{*}{ Daily Operations } & believed daily activities are focused on student learning \\
\hline & class programs are satisfactory \\
\hline & programs are checked \\
\hline \multirow{3}{*}{ Community of Learners } & $\begin{array}{l}\text { Believed they are given opportunities to work together although } \\
\text { methods vary }\end{array}$ \\
\hline & Stated that time for teacher reflection was never scheduled \\
\hline & $\begin{array}{l}\text { Saw that semestral break INSET is the only opportunity for in-depth } \\
\text { discussion of their need }\end{array}$ \\
\hline \multirow{3}{*}{ Best Practices } & Spent more time in planning than what they had don and its impact \\
\hline & Believed that best practices are adapted by schools \\
\hline & Required teachers to submit plans \\
\hline \multirow[t]{2}{*}{ Monitor curriculum alignment } & Provided feedback \\
\hline & Classroom walk-through \\
\hline \multirow{5}{*}{ Analyze student work } & Reviewing reports cards \\
\hline & Talking to students \\
\hline & Viewing samples of their work \\
\hline & Encourage teacher to utilize test results \\
\hline & Expected teachers to do their job \\
\hline \multirow{3}{*}{ Student reach learning potential } & Head teacher accountable for this \\
\hline & Believed they provided supports \\
\hline & Confirmed teachers are professionals \\
\hline \multirow{4}{*}{ Communication with staff } & Open door policy \\
\hline & Informal communication \\
\hline & Weekly assemblies \\
\hline & Expected teachers to communicate with parents \\
\hline \multirow{2}{*}{ Visibility } & Being in the hallways at recess/breaks/lunch hour \\
\hline & Attending school events \\
\hline \multirow{6}{*}{$\begin{array}{l}\text { Meaningful involvement from } \\
\text { parents }\end{array}$} & Believed they are \\
\hline & Maintaining communication \\
\hline & Talk to parents when there is a problem \\
\hline & Encourage volunteerism \\
\hline & Encourage teachers to invite parents \\
\hline & Encourage parent participation \\
\hline $\begin{array}{l}\text { Recognizing achievement and } \\
\text { improvement }\end{array}$ & Conduct of year-end awards program \\
\hline
\end{tabular}


Table 3 shows the summary of findings from the interviews of the 55 teachers handling Grade 6 students. These data describe the perception of each teacher on the day-today behavior of the school head.

The inclusion of the teachers as informants validates the responses of the school heads. According to Patton (2002), this method of triangulation contributes to the validity and credibility of the data analysis. Through this method, the data collected from the teachers' interviews were compared to the data collected from the school heads' interviews.

\section{Discussion}

The school heads' manifested behaviors were observed to be positive in all the five themes identified. There were clear manifestations of instructional leadership. For instance, all school heads expressed the importance of a clear vision: knowing where the school is going; what they stand for; and what they are working towards. It was clearly indicated that it was not individual but a shared vision. There were consistencies among all the school heads in managing certain areas of the instructional program. In the aay-to-day operations, the focus was on student achievement, which was manifested by programs, activities, projects and certain support systems already in place to accommodate the learning needs of students. The school heads also encouraged and supported individual professional development through reflection on the teachers' professional growth plans and discussion on the areas of growth from time to time. However, it was observed that there was lack of proper monitoring and evaluation.

There were inconsistencies among the school heads in managing other areas of the instructional program. All school heads embraced the importance of classrooms visitations to work with the teachers. However, this priority was not reflected in practice. Except for a few school heads, classroom visits were eliminated from their daily duties to make time for other matters perceived more compelling. Time was a factor and other duties took precedent over working with teachers. Even though school heads believed on the importance of monitoring the teaching by classroom visits, this was not manifested in the actual practice.

All school heads unequivocally stated that time was a limiting factor. All the good intentions were strongly interrupted by small administrative tasks setting instructional practices on least priority. For instance, school heads did not allot specific time to work with 
the teachers while the teachers were not given time to reflect and collaborate with colleagues on a regular basis. Everyone relied on professionalism that teachers were expected to perform their duties and held them accountable for student achievement.

Based from the teachers' perspectives, school heads were considered instructional leaders. The teachers were accountable for student achievement but provided with the necessary support. However, it was consistent that the school heads' monitoring of the teaching and learning through classroom observations, technical assistance, regular dialogue, conferencing and teaming with other teachers were lacking. The teachers believed that the school heads wanted to visit classrooms but they felt the day to-day pressures of running a school prevented them from completing walkthroughs. The teachers also felt recognized as professionals and trusted to do what was expected from them. From this premise, it was clear that the teachers' perception of the school head's responsibility was not focused on the teaching and learning.

The collaboration time for teachers was provided through professional development. However, both school heads and the teachers were not satisfied with the small amount of time to collaborate. The time allotment was not regular or long enough to build teacher capacity, which also required teachers to be away from their class. The teachers also believed that school heads created a community of learners to provide them with the opportunity to work together. It was assumed that once an opportunity to learn together was available, the application of learning to the classroom will provide the true meaning of a community of learners. This brings progress to the teaching practice.

In relation to the level of student achievement in Grade Six, the National Achievement Tests were analyzed by teachers to identify strengths and weaknesses in the teaching and learning. Although the NAT Average Mean Percentage Scores of school was below the national standards, consistent increase in the ratings was observed. The school heads' positive expectations and belief transcend to the teachers and students. It was evident that the day-to-day operations were connected to student achievement. For example, all the daily, weekly and monthly announcements were focused on school goals, celebration of student success, and issues that threatened the school climate. The visibility of the school head and the open door policy promoted positive relationships with the parents and the 
community. The school heads also addressed the relational aspects of leadership through communication, motivation, and facilitation. All of these contributed positively on the teaching and learning process.

Some of the pressing issues and concerns arising from the study data were sustaining time on task, balancing co-curricular activities, participating in competitions, and observing the affairs and events mandated by DepEd. School heads struggled with the quality of instructional time for learners and the time for special occasions and extra-curricular activities. In fact, one of them stressed the struggle to provide quality learning time as there are so many co-curricular activities such as assemblies, science, arts and cultural presentations and competitions, sports building activities and other activities and celebrations stipulated in DepEd School Calendar.

\section{Conclusion}

This study used qualitative research design to describe the instructional leadership practices of selected school heads in the City Schools Division of Tayabas City, Philippines. Using purposive sampling, a triangulation approach as used to interview a total of 55 teachers and 25 school heads who were responsible for grade 6 students. The 60-minute interviews were held at the school premises during the visitation and monitoring period. In addition, several documents were collected and analyzed including classroom walkthroughs and observations, grade level meetings, discussions with teachers about professional growth plans, school improvement plans, staff meeting minutes, quarterly accomplishment report, and achievement results analyses. The qualitative data were organized according to themes and categories.

The results of the study showed that most school heads carried out functions in the dimensions mission, managing curriculum and instruction, supervise and support teaching, monitoring student progress and promoting an effective instructional climate. A highly significant insight garnered was the consistency with the school heads' beliefs and intentions towards carrying out their duties that deal directly with teaching and learning. There was strong evidence of knowledge on instructional practices that guided the day-to-day activities. However, there was no proper monitoring and evaluation. The school heads just relied on the professionalism of teachers to ensure that duties were done. Being accountable to the student 
achievement was strongly communicated to the teachers, which the teachers carried out with conviction. The teachers' competencies, or the lack of it, have not been closely monitored and evaluated. Although school heads believed instructional directions were provided, the lack of structures and mechanisms to carry out directives were noticeable. It was concluded that school heads had more difficulties fulfilling duties related to teaching and learning than managerial functions.

The results of the study are beneficial to the school superintendent as baseline for the continuous improvement of the instructional leadership. It may also serve as basis for the evaluation of the effectiveness of the implemented professional development plan in the creation of more instructional leaders. It is highly beneficial for the conduct of further research correlating the instructional leadership with the students' academic achievement.

\section{References}

Adeel Ahmed Khan, Soaib Bin Asimiran, Suhaida Abdul Kadir, Siti Noormi Alias, Batool Atta, Bukar Ali Bularafa, Masood Ur Rehman (2020). Instructional Leadership and Students Academic Performance: Mediating Effects of Teacher's Organizational Commitment. International Journal of Learning, Teaching and Educational Research. Vol 19, No 10, https://doi.org/10.26803/ijlter.19.10.13

Auerbach, C, \& Silverstein, L. (2013). Qualitative data an introduction to coding and analysis. New York: New York University Press.

Brolund, L. (2016). Student Success Through Instructional Leadership. BU Journal of Graduate Studies in Education, Volume 8, Issue 2.

Carraway, J. H., \& Young, T. (2014). Implementation of a districtwide policy to improve principals' instructional leadership: Principals' sensemaking of the skillfull observational and coaching laboratory. Educational Policy, 29(1), 230-256. doi:10.1177/0895904814564216

DuFour, R., \& Marzano, R. (2011). High-leverage strategies for principal leadership. Educational Leadership, 66(5), 62-68.

Dutta, V. and Sahney, S. (2016), "School leadership and its impact on student achievement: The mediating role of school climate and teacher job satisfaction", International Journal of Educational Management, Vol. 30 No. 6, pp. 941-958. https://doi.org/10.1108/IJEM-12-2014-0170 
Fink, E., \& Resnick, L. (2013). Developing principals as instructional leaders. Phi Delta Kappan, 82(8), 598-606.

Fontana, A., \& Frey, J. (2015). The interview: From neutral stance to political involvement. In Norman K. Denzin \& Yvonna S. Lincoln (Eds.). Handbook on qualitative research (3rd ed.). (pp.695-727). Thousand Oaks, CA: Sage.

Hallinger, P. (2012). Research on the practice of instructional and transformational leadership: Retrospect and prospect. Bangkok, Thailand: College of Management, Mahidol University. Retrieved October 30, 2007, from www.cmmu.mahidol.ac.th/adminsystem/file_NEWS_document/Acer_Paper_Fina 1.pdf.

Heaven G, Bourne PA (2016) Instructional Leadership and Its Effect on Students' Academic Performance. Review Pub Administration Manag 4: 197. doi:10.4172/23157844.1000197

Hou, Y., Cui, Y. \& Zhang, D. Impact of instructional leadership on high school student academic achievement in China. Asia Pacific Educ. Rev. 20,543-558 (2019). https://doi.org/10.1007/s12564-019-09574-4

Jenkins, B. (2009). What It Takes To Be an Instructional Principal. January/February 2009

Johnson, D.M. (2006). Instructional Leadership and Academic Performance in Tennessee High Schools. PhD Dissertation, University of Tennessee. https://trace.tennessee.edu/utk_graddiss/4252

Leithwood, K., Jantzi, D., \& Steinbach, R. (2014). Leadership practices for accountable schools. In K. Leithwood \& P. Hallinger (Eds.). Second international handbook of educational leadership and administration. (Part 2, pp. 849-879). London, Great Britain: Kluwer Academic Publishers.

Liu, Y, Bellibas, M.S., \& Gumus, S. (2020). The Effect of Instructional Leadership and Distributed Leadership on Teacher Self-efficacy and Job Satisfaction: Mediating Roles of Supportive School Culture and Teacher Collaboration. Educational Management Administration \& Leadership. Vol 49, Issue 3. https://doi.org/10.1177/1741143220910438

McEwan, E. (2013). 7 steps to effective instructional leadership. Thousand Oaks, California: Corwin Press

Neuman, M., \& Simmons, W. (2014). Leadership for student learning. Phi Delta Kappan, 82(1), 9-12. 
Noor, Siti \& Don, Yahya \& Hussin, Fauzi \& Khalid, Rozalina. (2018). Instructional Leadership and Teachers' Functional Competency across the 21st Century Learning. International Journal of Instruction. 11. 135-152. 10.12973/iji.2018.11310a.

Null, J. W. (2011). Education and knowledge, not "standards and accountability": A critique of reform rhetoric through the ideas of Dewey, Bagley and Schwab. Educational Studies, 34(4), 397-413.

Patton, M. G. (2012). Qualitative Research and Evaluation Methods (3rd ed.). Thousand Oaks, California: Sage Publications.

Ross, J.A. \& Gray, P. (2006). School Leadership And Student Achievement: The Mediating Effects Of Teacher Beliefs. Canadian Journal Of Education, 29, 3 (2006): $7980 \overline{0} 822$

Ruebling, C.E. Stow, S.B. Kayona, F.A. \& Clarke, N.A. (2004). Instructional Leadership: An Essential Ingredient for Improving Student Learning. The Educational Forum, Volume 68, Spring 2004.

Sahlberg, P. (2015). Education policies for raising student learning: The Finnish approach. Journal of Education Policy, 22(2), 147-171.

Soy, S.K. (2007). The case study as a research method. Unpublished paper, University of Texas at Austin.

Zheng, H. (2010). School contexts, principal characteristics, and instructional leadership effectiveness: A statistical analysis. Paper presented at the annual meeting of the American Educational Research Association, New York, NY. 